\title{
Valgevene folkloristika õnnestumised ja valupunktid 21. sajandil
}

\author{
Tatsiana Valodzina \\ Valgevene Teaduste Akadeemia \\ kultuuri, keele ja kirjanduse uurimise keskuse \\ slaavi rahvaste folkloristika ja kultuuri osakonna juhataja \\ tanja_volodina@tut.by
}

\begin{abstract}
Teesid: Artiklis tehakse kokkuvõte valgevene folkloristika saavutustest 21. sajandil; selgitatakse välja folklooriuuringute kõige haavatavamad alad, üritatakse mõista rahvaluuleteaduse õnnestumiste ja puuduste põhjusi ning eeldusi.

Tuginedes analüüsile võib öelda, et järjepidev pöördumine rahvateaduste metoodikate käsitlemise poole, järkjärguline, ent kindel valgevene folkloori "antropologiseerimine" võimaldas meil alustada rahvaluule kui tervikliku ajaloolise ja kultuurilise nähtuse põhjalikku uurimist.
\end{abstract}

Märksõnad: antropoloogiline folkloor, etnolingvistika, maailmapilt ja -koodid, mütoloogia, žanrisüsteem, valgevene folkloor, väliuuringud

Tähtis ülesanne on Valgevene nüüdisaegse rahvaluuleteaduse perspektiivsete valdkondade määramine, saavutuste ja probleemsete valdkondade mõistmine, teaduslike andmete täiendamist ootavate lünkade hindamine ja määratlemine. Antud juhul ei ole eesmärk nentida, mida kirjutatakse, vaid analüüsida, miks kirjutatakse ja mis vaatenurga alt.

Kuni 2000. aastate alguseni domineeris Valgevene teaduslikus traditsioonis, mida arendasid peamiselt Kunstiteaduste, Etnograafia ja Folkloori Akadeemilise Instituudi folklooriosakonna teadlased, arusaam folkloorist kui suulisest rahvakunstist, sõnakunstist jne. Olles seni tegutsenud sellise mõistmise raames, astusid Valgevene folkloristid uude aastatuhandesse tohutu pagasiga - ilmusid sarja "Valgevene rahvakunst" (Беларуская народная творчасиь) viiskümmend köidet, kus olid esindatud peaaegu kõik suulise rahvakunsti peamised žanrid; sarja "Valgevene folkloor: žanrid, liigid, poeetika" (Беларускі фальклор: Жанры, віды, паэтыка, BF 2001-2004) kuus kokkuvõtvat raamatut; kaheköiteline entsüklopeedia "Valgevene folkloor" (Беларускі фбальклор, BF 2005-2006). Folklooriuurimise filoloogiliste traditsioonide kohaselt teostatud uurimused, mis põhinevad 19. sajandist 20. sajandi teise pooleni ilmunud klassikalise folkloori heliplaatidel, esitavad omamoodi kokkuvõtte materjali esialgsest kogumisest ja mõistmisest. Ent rahvakunstisari, mis oli valgevene 
folkloori rikkaim dokumenteeritud kogumik, pidas materjalide esitamisel kinni moodsa kirjaviisi normidest, mis kahjuks tasandas tekstide dialektilisi eripärasusi. ${ }^{1}$

Käesoleva aastatuhande alguses süvenes soov käsitleda tekstikogumeid mitte žanrilistes seostes, vaid keerulise koodisüsteemina, mille tõlgendamine viib loogiliselt kultuuri seisukohalt oluliste tähenduste tuvastamise ja kirjeldamiseni, sõltumata nende väljendumisvormist. Ühel või teisel määral kirjeldati järgmisi koode: ruumiline maastik; astronoomiline; ornitoloogiline; subjektiline ja somaatiline, animalistlik. Eriti põhjalikult on välja töötatud dendroloogilised ja värvikoodid Ina Švedi töödes (Šved 2006; Šved 2011), mis tõestab veenvalt, et "üksikute märkide uurimine väljaspool nende toimimise koodi, väljaspool pärimuskultuuri konteksti, ei võimaldanud avada folkloorsete sümbolite täielikku sisu" (Šved 2008: 5).

Fookuses ei ole enam konkreetne žanr või isegi suulise poeetilise loomingu tekst, vaid kultuuri sümboolne keeleühik. Seetõttu oli seaduspärane avaldada entsüklopeediline sõnaraamat "Valgevene mütoloogia" (Беларуская міфбалогія, BM 2004), mille on koostanud entusiastide meeskond erinevatest asutustest ja linnadest väljaspool institutsionaliseeritud projekti või rahastamist. Sõnavarakirjed koos eeldatavate mütoloogiliste tegelaste ja pühade lookustega tõid esile terve rea semiootilisi reaalsusi. Esimene trükk pälvis nii lugejate kui ka kriitikutest kolleegide vaimustuse. Peaaegu kohe pärast raamatu avaldamist algas selle täiendamine ja redigeerimine ning 2011. aastal ilmus uus "Valgevene mütoloogia” (MB 2011) trükk. Etnose mütopoeetilist maailmapilti esitati peaaegu tuhandes artiklis, mis paigutuvad temaatiliselt umbes viieteistkümnesse maailmapildi sisemist struktuuri korrastavasse põhi-koodi. Lisaks dokumenteeritud teabele valgevenelaste traditsioonilise vaimse kultuuri kõige mitmekesisematest aspektidest võimalikult pika ajavahemiku jooksul tutvustati lugejale uusi võimalusi folkloori uurimiseks väljaspool selle esteetilisi kriteeriume.

Filoloogiliseks analüüsiks kohustuslikest hüperboolidest ja kujundlikest parallelismidest loobumine käis käsikäes loobumisega ühe või teise žanri või süžee ainulaadsuse klišeedest, mis põhinesid ainult ühe valdkonna materjalidel; võimalusest näidata vanasõnadele või muinasjuttudele tuginedes etnilise mentaliteedi eripärasid. Aeglaselt, kuid kindlalt kadusid kirjutiste lehekülgedelt väited "iidse inimese igavese loodusehirmu kohta, mis põhjustas paljude folkloorižanrite tekke". Teadmatusega ühisest slaavi (rääkimata kogu Euroopa) vaatenurgast kaasneb sageli eksiarvamus valgevene folkloori iseärasustest. Valgevene folklooriuurimise arengut tänapäeval takistab tõsiselt ka asjaolu, et rahvuslikud uurijad jäävad keelebarjääri tõttu ilma oma Leedu kolleegide saavutustest. Just ühine minevik ja naaberlik lähedus aitaksid seletada paljusid arhailisi ja eriti intrigeerivaid fakte. 
Antropoloogilise folkloristika ideede aeglane, ent ühtlane levik kolmanda aastatuhande alguses on juba vilja kandnud. Avaldatakse monograafiaid, kus lisaks traditsioonilistele filoloogilistele meetoditele kasutatakse ka semiootilisi, kulturoloogilisi jms meetodeid. Vladimir (Uladzimir) Sivitski monograafias "Valgevenelaste muinasslaavi traditsioon: mütopoeetiline süsteem, tüpoloogilised paralleelid" (Русальная традиция белорусов: мифопоэтическая систела, типологические параллели) (Sivitski 2006) rekonstrueeritakse valgevenelaste vene kombestiku mütoloogiline mudel ühisel slaavi taustal. Tutvustatakse geneetilise seose kontseptsiooni merineitsi fenomeni ja selle vegetatiivse kultuse vahel, uuritakse loodusfilosoofilist ja sisult agraarset pragmaatikat ning selle abil kalendriaja määramist. Anastasiia Gulaki raamat "Petr Aleksejevitš Bessonov: slavist ja folklorist" (Петр Алексеевич Бессонов: славяновед и фбольклорист, Gulak 2008) on väärtuslik mitte ainult teadlase eluloo uute faktide ning tema loomingu ajastu kontekstis käsitlemise poolest, vaid ka selle poolest, et raamatus tõstatatakse esimest korda valgevene folkloristika ajaloos küsimus folkloori tekstoloogiast ja selle toimetamisest. Tänapäeval moodustab mittetseremoniaalne lüürika osa valgevenelaste igapäevasest ja pidulikust kultuurist. Ent mitterituaalsete lüüriliste laulude tüüpilised esitusviisid muutuvad oluliselt. See žanriliselt mitmekesine looming on folkloorsete tekstide kõrval hakanud aktiivselt asendama pere- ja kalendrikombestikuga seotud rituaalseid teoseid. Seejuures toimib laulu esitamine olukorra olulisuse markerina. Ianina Grõnevitši monograafias "Valgevene mitterituaalsed lüürilised laulud" (Белорусские внеобрядовые лирические песни), mis põhineb paljudel avaldatud ja arhiveeritud allikatel, uuritakse põhjalikult valgevenelaste vaimse pärandi olulist kihti - rituaaliväliseid lüürilisi laule (Grõnevitš 2018).

Käesoleva artikli autori monograafia "Inimese keha: sõna, müüt, rituaal" (Тело человека: слово, лифб, ритуал) (Valodzina 2009) on pühendatud "ihulise inimese" kuvandile ning ka etnomeditsiinile kui ühele maailma ja selles oleva inimese tõlgendamise vormile. Valgevene etnoanatoomiat ja etnomeditsiini esitatakse kui vaimse kultuuri fragmenti, mis on hästi säilinud, loogiliselt üles ehitatud, mütoloogilisi tähendusi täis ja erakordselt rikas spetsiifiliste folkloorsete ilmingute poolest. Inimkeha ja selle tervisega seotud seisukohtade ja rahvaluuletekstide kompleksi on kaasatud rohkelt sümboolseid seoseid, mis realiseeruvad spetsiaalsetes pragmaatilistes kontekstides (rituaal, maagia) ja igapäevaelus.

Ilmselt julgustab seni filoloogide pärusmaaks peetud traditsioonilise proosa poole vaatamine ületama žanrite puhtkirjandusliku lahterdamise piire. Ka kombestiku kogumine "vabastati mitmetest stereotüüpidest; leiti, et tohutut hulka nähtusi, mille folkloorses olemuses pole kahtlust, ei ole võimalik klassifitseerida tavapäraste meetoditega. Selles veendusid veelgi kindlamalt folkloristid, 
kes pöördusid varasemalt "suletud" või erinevatel põhjustel seni tähelepanuta jäetud kogude poole. Selgus, et žanris "raskesti tõlgendatavate ebaregulaarsete nähtuste arv on tohutu" (Britsina 2010: 65). Sellised asjaolud sunnivad esitama ettepanekuid uute klassifikaatorite loomiseks, mis põhjustavad siiski mõningaid vastuväiteid. Nii näiteks tõstab autorite meeskond Ryma Kavaleva juhtimisel (Kavaleva 2005; Kavaleva 2009) esile "maagilise proosa" - folkloori valdkonna, millel puuduvad žanrid. See sisaldab maagiliste tegudega seotud reeglite ja määratluste kogumit. Maagilisest proosast eralduvad kalendriga seonduv rituaalne ja kalendriga seotud pidulik proosa, ning taas tekivad küsimused kalendaarse rituaalse ja piduliku proosa eristamisest, rääkimata nende traditsiooniplokkide üldisest seosest proosaga.

Valgevene folkloori arengu praeguse etapi olulisimate suundumustena võib nimetada žanrite ja liikide aktualiseerimist, mis jäeti kunagi ideoloogiliste kaalutluste tõttu erialateaduse tähelepanuta. Uueks suundumuseks said rahvapiibli (Boganeva 2010) ja "julma romansi" (Kukreš 2010) tekstide kogumid. Elena (Alena) Boganeva koostatud rahvapiibli Valgevene väljaande ilmumine on folkloorse tekstoloogia ja rahvaproosa valdkonna spetsialistidele äärmiselt õigeaegne ja väärtuslik sündmus, kuna antud trükis tutvustab teadusringidele uut ja ulatuslikku autentset materjali ning kajastab Valgevene folklooritraditsioonide kogu mitmekesisust. Lisaks etioloogilistele ja eshatoloogilistele legendidele on kogumikus esindatud ja kirjeldatud sellised žanrimoodustised nagu rahvapiibli ümberjutustused, millel on kahtlemata folkloorne olemus, kuid mis ei sobitu ühessegi olemasolevasse rahvaproosa žanri. Raamat on varustatud motiivide registriga, mis kujutab endast juba praegu väärtuslikku allikat, mille abil saab materjali klassifitseerida, kataloogida ja kaardistada (vt selle kohta Belova 2012: 218-222). Boganeva jätkab edukalt rahvapiibli uurimist (Boganeva 2018a; Boganeva 2018c).

Üsna uue ja paljulubava trendina valgevene folkloori arendamisel tuleb ära märkida teiste slaavi rahvaste vaimsele kultuurile pühendatud väljaannete ettevalmistamist. ${ }^{2}$

Ja siiski peame tõdema: folkloori kõige huvitavamad ja märkimisväärsemad tulemused on saadud interdistsiplinaarses uurimistöös. Järjepidev pöördumine lähedaste rahvateaduste metoodikate poole, järkjärguline, ent kindel valgevene folkloori "antropologiseerimine" võimaldas meil alustada rahvaluule kui tervikliku ajaloolise ja kultuurilise nähtuse põhjalikku uurimist, kompleksselt ja integratiivselt tundma õppida protsesse, mis leiavad aset rahvapärimuses seoses ühiskonnas toimuvate muutustega.

Rahva vaimne kultuur on Valgevene etnolingvistide ja slavistide vaieldamatu uurimisobjekt. Teatud juhtudel aitavad välised paralleelid usaldusväärselt ja üsna produktiivselt kaasa Valgevene andmete rekonstrueerimisele üksikute salvestuste põhjal. Näiteks võimaldas Valgevene riituse Komoeditsa ja lõunaslaavi 
"karude" päevade kõrvutamine teha etnolingvistil Nikolai Antropovil huvitavaid järeldusi seoses motiiviga, kuidas objekt (kunagi tõenäoliselt tootem) saab üle kalendri ülemineku erinevatest etappidest (Antropov 2009). Märkimisväärne on teadlase töö Lääne-Polesje riituse "põõsas" geograafia, struktuuri ja semantika alal. Üldistades praeguseks kogunenud materjali, püstitas Nikolai Antropov hüpoteesi põuaga seotud riituse esialgsest juhuslikust vihmamaagilisusest, millele kihistusid aja jooksul tootva maagia elemendid, esialgselt reaalsete toimingutega, nagu näiteks pöörlemine/ümberpööramine või ringkäik väljadel, hiljem asendati tegevused "põõsa" lauludega (Antropov 2013).

Etnoloog Uladzimir Lobatši monograafia müütidest, kõiksusest ja inimesest (Мифб. Пространство. Человек: традииионный культурный ландшафбт белорусов в селиотической перспективе, Lobatš 2013) on pühendatud valgevenelaste traditsioonilise kultuurimaastiku nii looduslike kui ka inimtekkeliste põhielementide semantikale ja rituaalsele funktsionaalsusele nende suhete ja vastastikuse sõltuvuse süsteemis. Tuginedes etnograafilistele, folkloorsetele ja keelelistele andmetele ning suuresti ka omaenda uurimise käigus tehtud kirjetele, iseloomustab Lobatš valgevenelaste elupaiga kosmogoonilisi ja kosmoloogilisi parameetreid, mis kajastuvad traditsioonilise etnilise kultuuri kõigis ilmingutes. Ülevaade keskendub Valgevene maailmamudeli olemuselt ruumilisele ja samal ajal aksioloogilisele parameetrile - etnilisele territooriumile kõigis selle mütopoeetilise maailmapildi taksonoomilistes tasemetes. Mitmete originaalsete ja veenvate hüpoteeside ning kultuurimaastiku toimimise eri aspekte puudutavate arutelude seas on folkloristidele kõige väärtuslikumad mõistete sakraalne/püha/kultus kategoriseerimised, kohaliku ajaloo esemestamise mehhanismid etnilise ja laiemalt Euroopa ajaloo kontekstis, kuna iga legendaarne toopos fikseerib teatava kollektiivse ajaloo süžee, sõltumata selle mütoloogiast või tegelikkusest.

Püha maastiku uuringute jätku leiab lugeja Uladzimir Lobatši ja Tatsiana Valodzina monograafias "Valgevene pühad allikad" (Святые источники Беларуси). Raamat on pühendatud Valgevenemaa erilisele nähtusele kultusallikatele, mis on rahva seas tuntud juba ammusest ajast ja mida peetakse pühadeks. Allikate austamisega seotud valgevene legendid, traditsioonid, tervendamise imed, rituaalid ja kalendripühad on rikkalikult illustreeritud fotodega riigi eri osadest (Lobatš \& Valodzina 2016).

Filosoofi Siargei Sanko uurimused on keskendunud põhimõtteliste teoreetiliste probleemide lahendamisele: müüdi ja folkloori kui eriliste kultuurivormide seosele kultuuri semioloogias süsteemse dünaamilise lähenemise raames; rahvaluuleandmete kasutamise võimalustele ning piiridele müütide ja religiooni võrdlevates uuringutes peamiste mütoloogiliste teemade repertuaari rekonstrueerimiseks ja vastavalt sellele ka maailmavaadete ajaloos; mütoloogiliste teemade muundumise mehhanismidele mütoloogiliste, folkloorsete ja 
kirjanduslike narratiivide narratiiv-repertuaariks ${ }^{3}$ ning rahva- ja kirjanduslike tekstide elementide (ümber)mütologiseerimisele nii uuritavas traditsioonis kui ka pärimuse uurimise praktikas jne. Autori väljatöötatud strateegiate ja meetodite järjekindel rakendamine võimaldas teha järelduse, milline eriline koht oli valgevenelaste rahvakultuuri lähiajaloos tõenäoliselt kaksikteemal, mis killustub rahvaluule võrdlevates andmetes kolmeks põhinarratiiviks: kosmogoonilisel, etnilisel ja nn "kuninglikul narratiivil" (Sanko 2008; Sanko 2011; Sanko 2012). Siargei Sanko pöörab erilist tähelepanu "suurte narratiivide" dekonstrueerimisele - ideoloogilistele (kuid oma olemuselt mütoloogilistele) konstruktsioonidele, mida kasutatakse teadusuuringute seadustamiseks domineerivate distsiplinaarväljade raames, kus lingvistikas, folkloristikas ja muudes ajaloolise objektiga valdkondades on endiselt liiga autoriteetsed piibellik monogeneetiline narratiiv ja selle "sugupuu" skeemide kujul olevad allomorfid.

Etnograafilise ja folkloristliku materjali segunemine võimaldab rahvakunstialastes uurimustes süüvida kunstilise tegevuse antropoloogilistesse alustesse esemelise maailma loomisel. See näitab tänaseni rahvakunstis kasutatavate arhailiste rituaalide püsivust.

Tuginedes ikoonimängu riituse (гуляиь ікону) kohta Ida-Valgevene piirialadelt viimase aja jooksul kogutud välitööandmete analüüsile ja Siberialadele ümberasunud valgevenelaste seas küünla (Свячьь) ikooni ülekandumisele teeb Olga Lobatševskaja järelduse rahvakultuuri kohanemismehhanismide mitmekesisusest, mis veenab külaelanike traditsioonilist suhtumist ja nende religioossuse folkloorset iseloomu kajastava populaarse kristluse vormide elujõulisuses (Lobatševskaja 2007; Lobatševskaja \& Fedorov 2012). Arhailiste rituaalsete tavade, sealhulgas igapäevase riide valmistamise uurimine näitas, et rahvakombed jõudsid meie aega oma algkujul ja nad aktualiseeriti peaaegu kõikjal Valgevenes Teise maailmasõja ajal. Teadlase poolt igapäevase rituaali kohta kirjutatud tekstid annavad tunnistust Valgevene talupoja mütoloogilisest teadvusest ning ketramise ja kudumise mõistmisest kui maailma rituaalse muutmise vahenditest naiste subkultuuris (Lobatševskaja 2010).

Teatud määral sai valgevenelaste vaimse kultuuri üldistavaks uurimuseks Aliaksandr Lokotko toimetatud köide seeriast "Valgevene kultuuriajaloo piirjooni” (Очерки истории культуры Беларуси, Narõsõ 2013).

Etnolingvistiline suund on saamas moodsate fraseoloogiliste uurimistööde üheks prioriteediks, mille raames vaadeldakse fraseoloogiat kui tulemust ja samas ka kui kultuurilis-rahvusliku maailmapildi nägemise viisi ning selle semantika tõlgendamine viib uurija folklooritekstide juurde. Kõige täielikumad etnofraseoloogilised probleemid on esitatud Valgevene etnolingvistika tunnustatud juhi Vladimir Kovali töödes (Koval 2011). Viimastel aastatel väikestele rahvažanritele osutatud tähelepanu on süvenenud võrdlevate aspektide kaudu. Nii ilmus valgevene võrdluste sõnaraamat, mis hõlmab võrdlevate käänete 
kõige täiuslikumat koosseisu, sealhulgas võimsat murrete massiivi. Sõnastik on koostatud vastavalt Euroopa fraseoloogia klassikalistele parameetritele: iga stabiilne võrdlus on sertifitseeritud, esitatakse stiililine kirjeldus ja detailsed määratlused. Üksikutele võrdlustele pakutakse välja dialektismide kompaktne kirjeldus ning mõnikord ka ajaloolis-etümoloogilised kommentaarid. Ainult sõnastiku venekeelses osas esitatud definitsiooni peamine ülesanne on maksimeerida käibe semantikat ja selle konkreetset sidumist inimese, objekti, nähtuse või olukorraga (Volodina \& Mokienko 2018).

Siiani on erinevates teadusfoorumites ja eriti populaarteaduslikes väljaannetes retoorilise kujundina kõlanud tees valgevene folkloori erakordsest rikkusest Euroopa mastaabis, arhailiste tähenduste säilitamisest ning selle põhivormide ja tähenduste erilisest elujõust. Kogu paatose juures on sellel väitel mõjuv alus, kuivõrd klassikaline talupojakultuur on Valgevene külades säilinud tõesti oma autentses vormis, kuigi eraldi liikides - passiivses vormis (hoolimata asjaolust, et igal aastal ilmnevad asendamatud kaotused selle täiuses ja terviklikkuses). Seetõttu on Valgevene folkloristide olulisim töövaldkond jätkuvalt rahvusliku pärandi kinnistamine, põhitüüpide ja žanrite ja nende tüpoloogia väljaselgitamine, laulumeloodiate, tantsude, süžeede, motiivide ja kujutiste levikuala määramine, Valgevene Vabariigi piirkondlike ja kohalike eripärade kultuurimaastiku rikkust näitavate kogude ettevalmistamine.

Vaieldamatuks sündmuseks sai sarja "Valgevenelaste rahvakunst" (Традииионная художественная культура белорусов) avaldamine kuues köites (kümme raamatut) (TK 2001-2013). See on viimase kümnendi jooksul kirja pandud tekstide rikkalikem kogu, näide piirkonna kunstitraditsiooni põhjalikust uurimusest, mis tutvustab kalendri- ja perekondlikke kombeid ja rituaale, rituaaliväliseid laulusõnu ja instrumentaalmuusikat, tantsufolkloori, rahvamänge, rahvaproosat, väikseid žanre, süžeesid, rahvariideid ja rahvatekstiili. Kolm viimast köidet anti välja elektrooniliste rakendustega: autentsete laulude salvestused, instrumentaalmuusika ja rahvaproosa prominentsete lauljate, instrumentalistide ja jutuvestjate esituses. Tekstide autentsus, dialektiliste tunnuste täpne edastamine ja edastajate individuaalne rääkimisviis, tähelepanu kandmine kontekstile ja traditsioonikandjate isiklikele kogemustele, materjalide lai piirkondlik kajastus loovad mahuka panoraami Valgevene traditsioonilise kultuuri olemasolust praeguses etapis. Autorid (E. Boganeva, T. Varfolomeeva, T. Kukharonak, O. Lobachevskaya, N. Kozenko ja teised) püüavad näidata folklooritekstide otsest olemasolu kõigis seostes ja põimingutes nii etnilise rühma elus kui ka omavahelises seoses. Autorite meeskonna põhimõtteline seisukoht on idee autori ja sarja juhendaja, musikoloog T. Varfolomeeva sõnul piirkonna kultuuri vaatamine mitte ainult selle uurija poolt ja väljastpoolt, vaid ka seestpoolt, selle kandjate ja teadjate pilgu läbi (TK 2006: 6). Pärimuskultuuri "hääl” kõlab sarja igas osas: näiteks on 
kalendritraditsioonidele pühendatud osa esitatud mälestusmärkide vormis, saateks autori kommentaarid. Suulisi rahvapärimusi käsitlev osa (Вусныıя народныл дысскурсыь. Выказванні светапогляду) annab kõige olulisemates filosoofilistes ja moraalsetes küsimustes sõna traditsioonikandjatele, samuti pööratakse tähelepanu uskumuste, tavade, märkide ja ideede kirjeldusele koos nende emotsionaalse hinnanguga. Tavaliselt on diskursuses tutvustatav traditsioonikandjate taustateadmised justkui maailmavaatelise tähenduslik eeldus, vastupidiselt pärimuskultuuri narratiividele (lood, kirjanduslikud tekstid).

Laiemale lugejaskonnale on mõeldud kalendriaasta rituaale ja kombeid käsitlev väljaanne “Ядраное жыта гаспадара кліча...” (Valodzina \& Kukharonak 2015). Autorite poolt folkloori ja etnograafiliste ekspeditsioonide käigus kogutud rikkalik faktiline materjal annab tervikliku ülevaate valgevenelaste kalendrirituaalist, kui rahva elu kõige olulisemast valdkonnast ja alamsüsteemist, kus iga riitus, maagiline tegevus, laul või luuletus pidi aitama kaasa helde saagi, heaolu ning hea tervise saavutamisele. Autoriteksti põimitakse orgaaniliselt traditsiooni hääl - külaelanike endi lood, nende mälestused, emotsioonid, mured.

Kui 20. sajandi algust tähistas Vladimir Dobrovolsky koostatud Smolenski etnograafilise kogumiku avaldamine, siis 21. sajandi algus jätkas hea traditsiooniga: avaldati Polatski piirkonna etnograafiline kogumik, millest praeguseks on juba ilmunud kaks väljaannet, kumbki kahes raamatus (2006 ja 2011). See väljaanne tutvustab Vitebski piirkonna etnograafiliste uuringute käigus viimastel aastatel kogutud materjale. Kogumiku peamine ülesanne on esitada terviklik pilt Valgevene Podvinje traditsioonilise kultuuri hetkeolukorrast kogu selle mitmekesisuses. Seetõttu valisid koostajad materjali esitamise temaatilise põhimõtte, mis võimaldas oma piirkondlikus teostuses detailselt välja tuua ühe või teise rahvakultuuri valdkonna. Sari avati traditsioonilisele meditsiinile pühendatud numbriga, teine number keskendub rahvaproosale. Folkloorižanrid, mida see mõiste ühendab, on mitmekesised - etioloogilised legendid ja toponüümilised traditsioonid, mütoloogilised lood, perekonna ja piirkonna ajalooga seotud narratiivid, suuline ajalugu ja sõnas jäädvustatud folklooripilt maailmast (raamatusse on kantud 1483 teksti).

Tänapäeva kultuuripoliitikas, aga ka prioriteetsetes üldistes teoreetilistes rahvakultuuri käsitlustes, kerkib esile kohalike kultuuride traditsiooniliste vormide säilitamise (ja kindlasti uurimise) probleem. Üldisest etnilisest traditsioonist kandub rõhuasetus lokaalsetele piirkondlikele traditsioonidele. Folkloristid on tuvastanud mitmeid Valgevene kohalike kultuuride eripärasid, sarjas "Meie piirkonna folkloor" (Фольклор нашего крал), anti välja Elena (Alena) Boganeva koostatud kogumik, mis on pühendatud ühe piirkonna - Gomeli oblasti Oktjabrski rajooni - rahvaproosale. Kogumik on kaasaegne läbilõige traditsioonidest ja esindab kõiki rahvaproosa žanre ja tüüpe (Boganeva 2018b). 
Välitööde materjalide kogumikud on teadlasele alati hea kingitus, mille väärtus aja jooksul ei vähene, vaid ainult suureneb. Pealegi, kes saaks eitada traditsioonide maailma sukeldumise naudingut. Valgevene folkloori kogujate ja väljaandjate seast tuleks eriti esile tõsta Gennadi Lopatinit (Vetka rahvakunstimuuseum), kes on tuntud oma publikatsioonidega ajakirjades Elav Pärimus (Живая старина), Antropoloogiafoorum (Антропологический фборул) ja Palaeoslavica ning arvukate konverentside kogude ja materjalide poolest. Gennadi Lopatin (Lapatsin) suutis avastada, panna kirja, esitleda ja lisada professionaalseid kommentaare haruldaste heasoovijate, näkineidude, vandenõude, küünla riituse jms kohta (Lapatsin 2013; Lopatin 2008). Eriti väärtuslik on see, kuidas ta kujutab inimest pärimuses, ta vormib folkloorilis-etnograafilise portree - antud juhul Varvara Gretskaja - andekas iseõppija, kellelt registreeriti ja esitati tuhandeid folklooriüksusi (Lapatsin 2015). Tšernobõli tuumaelektrijaamas toimunud õnnetuses kannatadasaanud ümberasustatud külade folkloorile on pühendatud eraldi kogumik (Pesni 2016).

Eespool nimetatud viimaste aastate publikatsioonid, nende autorite ja koostajate teaduslikud lähenemised veenavad meid taas, et kultuuri pinnapealne jagamine materiaalseks ja vaimseks on jäämas minevikku, tähelepanu keskpunktis on traditsioonide inimene. Oma eeliseid näitavad kohapeal tehtud intervjuud, vestlused kohalike elanikega, edasirääkijate detailsed lood, mis ületavad kahtlemata folkloori kabinetižanri rubriiki ja esindavad sageli hinnanguid, põhjendusi ja järeldusi. Sellised tekstid on eriti väärtuslikud maailmapildi fokuseerimisel ja on usaldusväärseks allikaks Valgevene traditsioonilise kultuuri hetkeolukorra uurimisel.

Endiselt on terava probleemina üleval kvaliteedi ja kahjuks ka kogutud materjali autentsuse küsimus, eriti kui tegemist on tudengi tehtud kirjetega. Veidrustena tajutakse 80-90aastaste vanamemmede tarkusi, nagu näiteks "peegel on slaavi uskumuste kohaselt aken teise maailma" või sellised "võlud" nagu "näkineidude sabad särasid kuuvalgel". Ja kuidas oli võimalik uskuda naiivset, külapeo ideest aimu mitteomavat õpilast, kes "pani kirja”, et vanamemmed istusid pidulikul lihavõttepäeval pingil ja mängisid mängu "kes mäletab rohkem vanasõnu ja ütlemisi kevade kohta"?! Sellegipoolest koguvad kergeusklikud folklooripraktikute juhendajad selliseid materjali arhiivi ja mitte vähem kergeusklikud koostajad lisavad neid tekste rahvaluulekogudesse. Kahjuks on Gomeli folkloori piirkondlikes kogudes palju selliseid näiteid, mis õõnestab märkimisväärselt usaldust muude nimetatud kogudes sisalduvate materjalide vastu. Kuid pole kahtlust, et ilmselgete tudengiapsude seas leidub ka rahvatarkuste kullateri.

Tekib küsimus, kas tõesti on nimetatud halva kvaliteediga väljaanded nii ohtlikud - need näitavad ju noorte "sisseelamist" traditsioonidesse, soovi luua isiklikke "vanamemmede lugusid" konkreetse tegelase, žanri kohta saadud 
teadmistele tuginedes ehk teisisõnu näitavad ju need noorte otsest huvi rahvapärimuse vastu. Siiski tuleb meeles pidada, et kontrollimata andmete kasutamine (tavaliselt populaarsetest raamatutest kogutud) või isegi valeandmete dubleerimine viib teadlikult valede järeldusteni kogu pärimuse kohta.

Eelkõige hõlmab tudengifabritseeringute laine kõige köitvamat ja samas kõige haavatavamat folkloori kihti - tegelaskujusid. Muide, just entsüklopeedilisse valgevene mütoloogia sõnaraamatusse (Беларуская ліббалогія) lisatud mütoloogiliste tegelaskujude koosseis sai kriitikutelt kõige rohkem märkusi, seda peamiselt juba 19. sajandi keskel Pavel Špilevski poolt välja pakutud "panteoni” tõttu. Andekas ajakirjanik, kirjanik Pavel Špilevski avaldas 23aastaselt varjunime P. Drevljanski all teoseid Valgevene rahvapärimusest (Белорусские народные предания, Drevlyansky 1846). Pidagem meeles, et 19. sajand möödus nn mütoloogilise kooli sildi all, mille esindajad püüdsid muu hulgas rahvuslikke mütoloogiaid "rekonstrueerida" vastavalt "rahvusvahelistele" standarditele, mille eeskujuks olid eelkõige klassikalised antiikaja näited. Siinkohal võib meenutada näiteks Poola ajaloolase Jan Dlugoshi varasemaid katseid teoses "Historia Polonica", kus luuakse Poola panteon, mis sarnaneb antiikse panteoniga või isegi Mihhail Lomonossovit, kes tõmbas paralleele Rooma ja Vene jumaluste vahele. Valgevene rikkalik pärimus, mis kajastus ka folklooris ja tavalise valgevenelase eluviisis, sobis suurepäraselt oma mitmekesisuses õpetatud meeste pakutud konstruktsioonidega.

Alates 1846. aastast on teaduslikes uuringutes figureerinud Gartsuki, Devoja, Borzdja, Shatavila ja teised Špilevski pakutud tegelaskujud. Ent osa Pavel Špilevski esitatud teabest ei leia kinnitust ühestki allikast, välitööde materjalides neid andmeid ei leidu, ning see tekitab teatavaid kahtlusi üksikute tegelaste autentsuses. Drevljanski teose aadressil on korduvalt tehtud kriitikat ${ }^{4}$. Pole kahtlust, et noor autor siiski reisis mööda Valgevenemaad ja kirjutas palju üles, olles haritud ja tähelepanelik oma emakeele suhtes ning säilitades muistseid elemente. Seetõttu tundub õigem mitte jätta Špilevski märkmeid tähelepanu alt välja, kuid nende suhtes tuleb olla teaduslikult kriitiline. Teadusajalugu on korduvalt tõestanud, et üksikud unikaalteated on teadmiste edasiarendamisel sama olulised (kui mitte olulisemad) kui massiliselt fikseeritud (s.t. üldiselt reprodutseeritavad) faktid. Piisab, kui mainida võrdluseks Hesychiuse "Leksikoni" (ja mitte ainult keelelisest aspektist).

Paradoksaalne tundub mitte noore romantiku loodud teos, vaid pigem selle pretsedenditu edu Valgevene etnoloogias (ja mitte ainult) - Valgevene mütoloogia kirjeldusele sajanditeks avaldatud mõju. Vaatamata kõikidele kahtlustele, mida väljendasid asjatundjad oma teaduslikes kirjutistes, elasid traditsioonid koos Valeri Slavuki imeliste illustratsioonidega üle mitu kordustrükki ja said tõelisteks bestselleriks. Ja koos sellega atraktiivseks jäljendamise allikaks. Špilevski teoseid kasutatakse kahtlemata ka tänapäeval “teaduslikes” töödes, 
tudengid "salvestavad" andmeid armastajate kohta ning mitte vähem romantilised folkloristid-õpetajad avaldavad neid oma kogudes. Üliõpilasloome on ilmne ka samal territooriumil tehtud professionaalsete folkloristide salvestuste taustal. Muidugi mängisid tegelikkusele mittevastavate andmete ja tegelaste tiražeerimisel oma osa Valgevene mütoloogiasõnastiku kaks esimest trükki; kolmandas trükis on vastavatesse artiklitesse lisatud kommentaarid ("Špilevski poolt välja pakutud tegelane", "andmed tema kohta ei leia täiendavat kinnitust” jne). Seega väljendame austust ja tunnustust Špilevski inspireerivale loomingule ja lisame osa tema andmetest teaduslikku ringlusse, ent arvestame seejuures etnoloogiaõpetuses 19. sajandi keskel valitsenud taset.

Austust ja kiitust väärib huvi kohaliku pärimuskultuuri uurimise vastu, mida näitavad ka teatud piirkondade arvukad rahvaluulekogumikud, mille koostasid Gomeli folkloristid Valentina (Valjantsina) Novaki juhtimisel. Antud juhul tuleks välitööde kirjete kvaliteeti arutamata märkida, et nimetatud väljaanded on olulised just nendele kohalikele kogukondadele. Lõppude lõpuks on individuaalse identiteedi probleem lahendatav kohaliku kultuuri valdkonnas, mille traditsioonide ja sügavate tähendustega ta end identifitseerib. "Väikese kodumaa" kohalik kultuur kannab edasi moraalsete kohustuste tähendusi, norme, käitumist ja suhteid looduskeskkonnaga, esteetilisi kriteeriume, mis on kohalikus kogukonnas traditsiooniliselt välja kujunenud igapäevaste, pühade ja ajalooliste kogemuste põhjal.

Eraldiseisvate, enamasti kirjeldavate informatiivsete väljaannete olemasolu korral jääb linna-, tudengi-, sõduri-, kriminaal- jm folkloor endiselt suletuks. Siin on mitu põhjust: tohutu kogumis- ja tõlgendamisala pakub jätkuvalt traditsioonilist, maalähedast folkloori, peaaegu igal ekspeditsioonil tunneme rõõmu uute (mõnikord ainulaadsete) avastuste üle, mis ootavad nende teaduslikku tuvastamist ja süsteemi lisamist; linnafolkloori ja postfolkloori mõjutab peaaegu eranditult venekeelne sisu, mis põhjustab selle teatud tõrjumist; riigis on puudu mitte ainult sobiv kool, vaid ka metoodilist laadi individuaalsed kokkuvõtlikud tööd (mis tuleneb loomulikult eeltoodud põhjustest). Teadlaste jõupingutused on keskendunud sobivate vahendite väljatöötamisele, mitte ainult traditsiooni hetkeseisu uurimiseks, vaid ka folkloori ja mütoloogiliste mudelite mõju tunnuste määratlemiseks reaalsuse tõlgendamisel, sealhulgas linnarahva seas. "Koos arusaamisega, et folkloori ja mütoloogiliste süsteemide transformatsioonid toimusid pidevalt isegi kauges minevikus - esindades loomulikku reaktsiooni kultuurilistele, religioossetele, majanduslikele, poliitilistele muutustele - tuleb ka arusaam ebaproduktiivsest pöördumisest mingi määramatu laialt tõlgendatud ajaloolise arhailise mõiste poole" (Šved 2011a: 5-6).

Täna on Valgevene kultuuriruumis väljakujunenud suund, mida võib määratleda kui meelelahutuslikku folkloristikat või põnevat mütoloogiat. Selle suuna raamatuid iseloomustab autori teatud subjektiivsus, ilukirjandusstiili 
ülekaal, võrdlusaparatuuri puudumine või ebatäiuslikkus. Siiski väärib märkimist, et nimetatud väljaanded toetavad inimeste huvi rahvakultuuri vastu ja aitavad seda populariseerida. Lõpuks tuleb tunnistada, et Valgevene folkloristide vahel puudub ühtsus, mis on iseenesest normaalne, sest ainult seisukohtade erinevus on iga teaduse arengu loomulik ja vajalik tegur, mis võimaldab uurimistööl edasi areneda. Ent seni on välja töötamata avalike teaduslike arutelude objektiivsed mehhanismid, mis võimaldaksid kriitiliselt hinnata uut kirjandust, vaidlust tekitavate küsimuste arutamiseks puudub avaldamisplatvorm jne. Riigis ei ole piisavalt spetsialiste, et blokeerida ebateaduslikke väljaandeid, mis uhkeldavad kõlavate nimetustega. Pseudoteadusliku kirjanduse mahu järsk kasv vähendab olemasoleva filtri võimalusi. Ilmselt on meie ajastul ainus ja kõige usaldusväärsem viis teaduse olukorra kontrollimiseks kvaliteetsete erialaste tekstide avaldamine. Kui on mida lugeda ja millega võrrelda. Tõepoolest, tõmbavad ju tühimikud ühes või teises valdkonnas vastavalt loogikaseadustele enda poole ja need tuleb täita. Puudub kvaliteetne erialakirjandus, puudub niivõrd oluline konkurents - tühimik täidetakse sellega, mis ilmub esimesena ja suurema tiraažiga.

Just sellega võib seletada Ivan Kruki ja Oksana Kotovitši raamatu "Rahvakultuuri kuldreeglid" (Золотые правила народной культурь) erakordset populaarsust (Kotovitš \& Kruk 2010). Ühiskonnas, kus kogetakse tõelist “allikate poole pöördumise" taassündi, mil aktiviseeritakse rakendusliku olemuse teadmiste päringud, mil mitte ainult talupojad ja eilsed külaelanikud, vaid ka linnarahvas soovib pidada perekondlikke pidustusi ja teha majapidamistöid "nagu tegid meie vanaisad ja vaarisad", on juba pikemat aega tunda vajadust sellise tegevusjuhendi järele. Ja see teos ilmus. Pidas vastu tervelt seitse trükki, tiraažiga 19000 eksemplari (tavapärane rahvaluule-alaste raamatute tiraaž on 100-300 eksemplari). Raamat sai 2011. aastal kümne enimmüüdud raamatu edetabelis kuuenda koha. Ja kuidas saakski olla teisiti, sest nii nagu viidatakse ka annotatsioonis, võimaldavad "kuldreeglid" "säilitada oma juurte mälu, turgutada oma suguvõsa elupuud, täita seda esivanemate sajandite-pikkuse tarkuse tervendava jõuga ning aidata seeläbi kaasa tsivilisatsiooni arengule tervikuna".

Kahju on vaid sellest, et kõikideks elujuhtumiteks, isegi "kui last pekstakse koolis" pakutakse Valgevene ja Venemaa väljaannetest, sealhulgas N. Stepanova loitsukogumiku laadsetest väljaannetest, kogutud kategoorilisi väiteid, mis arvestamata kohaliku rahvakultuuri eripära ning traditsioonikandjate konfessionaalset kuuluvust soovitavad ainult primitiivset maagiat. Raamatu üheks märgatavamaks puuduseks näib olevat selle depressiivne mõju lugejale, kui soovitused rõhuvad oma kategoorilisusega ning soovituste mittejärgimine lootusetusega. Näiteks "viimane teekond - maja juurest kalmistu väravani viiv tee tuleks tähistada kuuseokstega; seejuures tuleb meeles pidada, et oksi 
peab jätkuma lähima ristmikuni (kõige sagedamini linnas) või küla lõpuni. Kui mingil põhjusel jääb okstest puudu, võid see põhjustada selle perekonna esindaja surma" (Kotovitš \& Kruk 2010: 223). Teistes "reeglites" ennustatakse ettekirjutuste täitmatajätmisel (ettekirjutus kehtib piiratud territooriumil) kõikidele lugejatele (venekeelne raamat keskendub keelekasutajate rohkusele) kategooriliselt hädasid ja kohutavaid haigusi.

Arutledes folkloristi kasvatamise ja tema rolli üle ühiskonnaelus, jõuame järeldusele, et Valgevene olukord on üsna tähelepanuväärne. Meenutagem kasvõi folkloori rolli etniliste müütide loomisel, mille eesmärk oli tugevdada rahvast 1920. aastatel ja Valgevene renessanssi teise laine ajal 1990. aastatel. Just folkloor oli ideaalne materjal rahvusliku ühtsuse idee, selle kuulsusrikka mineviku konstrueerimiseks, mis võiks julgustada sama kuulsusrikka tuleviku ehitamist. Selleks, et folkloor täidaks oma eesmärke, suhtuti sellesse alates Špilevskist üsna vabalt, seda parandati ja loodi uut folkloori. Eelmise sajandi alguses oli rahvusmütoloogia konstrueerimise eredaks näiteks Vaclav Lastovsky looming, mõned tema sulest pärinevad folkloori nimetusele pretendeerivad legendid said kultuuri- ja uurimisruumi osaks.

Nõukogude-järgsel perioodil hoogustus kodu-uurimise liikumine, mille puhul pööratakse erilist tähelepanu peamiselt toponüümilise iseloomuga legendidele ja traditsioonidele, mis seostub "väikese kodumaa" populariseerimisega. Olulisem on aga asjaolu, et pöördumine rahvaluule poole ja katsed seda mõista näitavad viimasel kümnendil kindlalt noorte valgevenelaste "teadlikkust", noored üritavad seeläbi kinnitada venekeelse ja enamasti ükskõikse avalikkuse silmis oma rahvuslikku identiteeti ja ühiskondlikku positsiooni. Selliste liikumiste tohutu väärtusega kaasneb ka teatud puudus, mis on seotud teadliku rahvaluulega manipuleerimisega, et realiseerida üksikute "juhtide" teatud ambitsioone (näiteks imperialistlikud ideed, "slaavi ühtsuse" ideed jne). Lisaks ilmub ajakirjanduses ja suuremal määral ka internetiavarustes rahvakultuuri entusiasmi lainel amatöörlikke "arhailiste tähenduste rekonstrueerimisi", mis mõjutavad kahjuks isegi üksikute professionaalsete folkloristide vaatepunkti.

Valgevene Teaduste Akadeemia Kunstiteaduste, Etnograafia ja Folkloori Keskus alustas 2013. aastal teadusartiklite kogumiku "Valgevene folkloor: materjalid ja uurimused” (Беларускі фбальклор: матэрыяль і даследаванні) (реаtoimetaja Tatjana Volodina) perioodilist väljaandmist (täpsemalt vt Valodzina 2017). Väljaandest on juba saanud viljakas ja huvitav platvorm folkloori aktuaalsete probleemide arutamiseks. Uuringud sisaldavad Valgevene folkloori põhisuundi, uusi lähenemisviise valgevenelaste vaimse kultuuri traditsioonilise maailma uurimiseks ja mõistmiseks.

Tõlkinud Karin Sahar-Lambinen 


\section{Kommentaarid}

1 Kahjuks võib ka tänapäeval sageli kohata fakte rahvaluulekirjete kohandamisest kirjakeelele vastavaks.

${ }^{2}$ Ivan Tšarota koostas kogumikud serblaste kombestikust, pühadest ja pühakutest (Народ сербскі: яго абрады і звычаі, святы і святыні. Tšarota 2006, 2009, 2012), lüürilise ja eepilise luule antoloogia ning serbia rahvaproosa "Srpska kizhevnost" (Tšarota 2002). Ina Švedi monograafias "Словацкий фольклор: формы, жанры, поэтика" (Šved 2010) määratletakse slovaki rahvatraditsiooni mütoloogilised ja kunstilised nähtused.

3 Narratiivi (ingl narrative) all mõistetakse tänapäeva narratoloogias elementaarset narratiivüksust, mis ei pruugi tingimata motiiviga kokku langeda. Motiiv on narratiiv, mida tõlgendatakse jutustatava teksti struktuuris teatud viisil, kuna süžee ei ole invariant, sõltudes selle aluseks olevast maailmapildist. Narratiivide kogum, millest "jooksevad läbi" (A. N. Vesselovski väljend) teatud tüüpi jutustavad tekstid, moodustavad seda tüüpi tekstide narratiivide repertuaari.

4 Antud teema kohta esitasid kriitilisi märkusi ka A. Potebnja, A. Põpin, I. Nossovitš, hiljem jõudsid I. Tishchenko, G. Kisseljov, G. Kohhanovski; A. Toporkov (Toporkov 2002) ja E. Levkievskaja järeldusele, et see töö on "nooruslik hobi", mida tuleb pidada teaduslikult ebaküpseks. Ühtlasi leiab Levkievskaja hoolika analüüsi tulemusel entusiastlikule autorile vabanduse, kui viimane on "püüdnud käsitleda teksti advokaadi seisukohast niivõrd, kuivõrd autor selle võimaluse annab": "Valgevene rahvapärimused on muidugi võltsingud, kuid seejuures üsna nutikad ja isegi keerukad, loodud inimese poolt, kes kohtles Valgevene rahvakultuuri nii hoolikalt, kui seda lubas võltsija olemus... Drevljanski tundis rahvakultuuri väga peenelt, täpsemalt selle "nõrku" kohti, mida saab kasutada võltsingute alusmaterjalina" (Levkievskaja 2002: 348-349).

\section{Kirjandus}

Antropov 2009 = Antropov, Nikolai 2009. Belorusskaia komoeditsana na fone iuzhnoslavianskikh "medvezh'ikh" dnei i ritualov. Slavianskie iazyki: aspekty issledovaniia: sb. nauch. st. Minsk: BGU, lk 13-19 (https://docs.google.com/file/d/0B8J Iri4nKuARQzQyUUIVaEtTT3VTWWhCRINoTW12UQ/edit - 29. oktoober 2019).

Antropov 2013 = Antropov, Nikolai 2013. Belorusskie etnolingvisticheskie etiudy: 3. "Kust" (chast' pervaia). Ethnolinguistica Slavica: K 90-letiiu akademika Nikity Il'icha Tolstogo. Moskva: Indrik, lk 162-179 (https://inslav.ru/sites/default/files/editions/2013_ ethnolinguistica_slavica.pdf - 29. oktoober 2019).

BF 2001-2004 = Belaruski fal'klor: zhanry, vidy, paetyka 5 köidet. Lis, Arsen' \& Gurski, Anton \& Sharaia, V. \& Savitski, U. (koost) 2001. 1. raamat. Kaliandarna-abradavaia paeziia. Minsk: Belarus'. Fiadosik, Anatol' \& Emial'ianay̆, Anatol' \& Sysoy̆, Uladzimir \& Kaladzinski, Mikalai 2001. 2. raamat. Siameina-abradavaia paeziia. Narodny teatr. Minsk: Belaruskaia navuka. Gurski, Anton \& Piatroy̆skaia, Galina \& Salavei, Liia 2002. 3. raamat. Pazaabradavaia paeziia. Minsk: Belaruskaia navuka. Kabashnikay̆, Kanstantsin \& Fiadosik, Anatol' \& Tsitavets, Aliaksandr 2002. 4. raamat. Narodnaia proza. Minsk: Belaruskaia navuka. Nenadavets, Aliaksei \& Kabashnikaŭ, Kanstantsin 
\& Lis, Arsen' \& Fiadosik, Anatol' 2003. 5. raamat. Mifalogiia. Dukhoy̆nyia vershy. Minsk: Belaruskaia navuka. Valodzina, Tatsiana \& Fiadosik, Anatol' 2004. 6. raamat. Malyia zhanry. Dzitsiachy fal'klor. Minsk: Belaruskaia navuka.

BF 2005-2006 = Belaruski fal'klor. Entsyklapedyia (kahes köites). Minsk: Belaruskaia entsyklapedyia.

BM 2004 = San'ko, Siargei (koost) 2004. Belaruskaia mifalogiia. Entsyklapedychny sloy̆nik. Minsk: Belarus'.

Belova 2012 = Belova, Olga. Narodnaja Biblija [Folk Bible] (Reviews for the publication: Boganeva Alena. Belaruskaya "narodnaya Bíblíya" ŭ suchasnykh zapísakh: Ustupny artykul, ukladanne í kamentaryí. [Belarusian Folk Bible in Modern Records: Introductory Article, Compilation and Comments]. Arche 5 (116), lk 218-222.

Boganeva 2010 = Boganeva, Alena (koost). Belaruskaia "narodnaia Bibliia” y̆ suchasnykh zapisakh. Minsk.

Boganeva 2018a = Boganeva, Alena 2018. Vobraz Vavilonskai vezhy y̆ belaruskai narodnai Biblii: matyvy, etyialogii, paraleli, vobrazy. Belaruski fal'klor: Materyialy $i$ dasledavanni 5. Minsk: Belaruskaia navuka, lk 164-175.

Boganeva 2018b = Boganeva, Alena 2018. Narodnaia proza Aktsiabrshchyny. Fal'klor nashaga kraiu. Minsk: Belaruskaia navuka.

Boganeva 2018c = Boganeva, Alena. Contemporary recordings of belarusian folk biblical and non-biblical etiological legends in the comparative-historical aspect. Folklore: Electronic Journal of Folklore 72, lk 59-88 (doi: 10.7592/FEJF2018.72.boganeva).

Britsina 2010 = Britsina, Aleksandra. Problemnoe pole sovremennoi ukrainskoi fol'kloristiki. Dobrovolskaia, V. \& Kargin, A. (koost). Ot kongressa $k$ kongressu: Navstrechu Vtoromu Vserossiiskomu kongressu fol'kloristov. Sbornik materialov. Moskva: Gosudarstvennyi respublikanskii tsentr russkogo fol'klora, lk 63-76.

Grõnevitš 2018 = Grynevich, Ianina. Belaruskiia pazaabradavyia lirychnyia pesni . Minsk: Belaruskaia navuka.

Gulak 2008 = Gulak, Anastasiia. Petr Aliakseevich Biassonaỹ: slavianaznaỹtsa $i$ falklaryst. Minsk: Zorny verasen'.

Drevljanski 1846 = Drevlianskii, Petr. Belorusskie narodnye pover'ia. Zhurnal Ministerstva narodnogo prosveshcheniia. Pribavleniia. Kn. 1.-4. Sankt Petersburg.

Kotovitš \& Kruk 2010 = Kotovich, Oksana \& Kruk, Ivan. Zolotye pravila narodnoi kul'tury. Minsk: Adukatsyia i vykhavanne.

Kavaleva 2005 = Kavaleva, Ryma. Abrysy rytual'na-magichnai sfery belaruskaga fal'kloru. Minsk: Bestprynt.

Kavaleva 2009 = Kavaleva, Ryma. Fal'klarystychny kaleidaskop: zbornik artykulay̆. Minsk: Bestprynt.

Koval 2011 = Koval', Vladimir. Frazeologiia narodnoi dukhovnoi kul'tury: sostav, semantika, proiskhozhdenie. Minsk: Respublikanskii institut vysshei shkoly.

Kukreš $2010=$ Kukresh, Alena (koost). Zhorstki ramans: fal'klornyia pesni. Minsk: Knigazbor. 
Labatševskaja 2007 = Labachey̆skaia, Vol'ga. Abrad "guliats' ikonu" iak praiava narodnaga khrystsiianstva na belaruska-rasiiskim pamezhzhy. Smułkowa, Elzbieta \& Engelking, Anna (toim). Pogranicza Biatorusi $w$ perspektywie interdyscyplinarnej $=$ Pamezhzhy Belarusi y̆ mizhdystsyplinarnai perspektyve. Warszawa: Dig, lk 404-430.

Lapatsin 2013 = Lapatsin, Genadz'. "Ikona zvalas' sviachoi...". Abrad "Sviacha” y prastory tradytsyinai kul'tury Gomel'shchyny. Gomel': Bark.

Lapatsin 2015 = Lapatsin, Genadz'. Varvara Gretskaia iak z’iava belaruskai narodnai kul'tury. Gomel': Bark.

Levkievskaja 2002 = Levkievskaia Elena. Mekhanizmy sozdaniia mifologicheskikh fantomov v "Belorusskikh narodnykh predaniiakh" P. Drevlianskogo. Toporkov, Andrei (koost). Rukopisi, kotorykh ne bylo... Poddelki v oblasti slavianskogo fol'klora. Moskva: Ladomir, lk 311-352 (http://folk.spbu.ru/Reader/levkilevskaja2.php?rubr=Readerarticles - 1. november 2019).

Lobatš 2013 = Lobach, Uladzimir. Mif. Prastora. Chalavek. Tradytsyiny kul'turny landshaft belarusai u semiiatychnai perspektyve. Minsk: Tekhnalogiia.

Lobatš \& Valodzina 2016 = Lobach, Uladzimir \& Valodzina, Tatsiana. Sviatyia krynitsy Belarusi. Minsk: Belaruskaia navuka.

Lobatševskaja 2010 = Lobachevskaia, Ol'ga. Ritual v povsednevnosti voiny (ob arkhaicheskoi ritual'noi praktike v gody Vtoroi mirovoi voiny v Belarusi). Homo historicus 2009: gadavik antrapalagichnai gistoryi. Vil'nia, 2010, lk 43-53.

Lobatševskaja \& Fedorov 2012 = Lobachevskaia, Ol'ga \& Fedorov, Roman. "Svecha" v Sibiri: etnograficheskii i kul'turo-antropologicheskii aspekty bytovaniia obriada $\mathrm{u}$ belorusskikh pereselentsev. Vestnik arkheologii, antropologii $i$ etnografii 1 (16), lk 72-82.

Lopatin 2008 = Lopatin, Gennadii. O narodnoi demonologii belorussko-brianskogo pogranich'ia: dobrokhozhie, nevidimye i dr. Palaeoslavica, XVII (2).

MB 2011 = Klimkovich, Iryna \& Ay̆tushka, Viktar (koost). Mifalogiia belarusay̆. Entsyklapedychny sloy̆nik. Minsk: Belarus'.

Narõsõ 2013 = Lakotka, Aliaksandr (tead toim). Narysy gistoryi kul'tury Belarusi 3. kd, 2. rmt. Minsk: Belaruskaia navuka.

Pesni 2016 = Mazuryna, Natallia \& Niachaeva, Galina \& Valodzina, Tatstsiana \& Patsiupa, Iuras' (koost, toim). Pesni pakinutykh vesak. Minsk: Belovagrupp.

Sanko 2008 = San'ko, Siargei. Dukhoy̆naia peradgistoryia Belarusi: svet - sotsyum chalavek u mifa-paetychnai kartsine svetu. Gistoryia filasofskai i gramadska-palitychnai dumki Belarusi u 6 t. T. 1 Epokha Siaredniavechcha. Minsk: Belaruskaia navuka, lk 137-232.

Sanko 2011 = Sanko Sergey. Belarusian Ethnogonic Legend in the Context of Vedic Twin Mythology. Dash, Padma Lohan \& Yerekesheva, Laura \& Misra, Neeru (toim). India and Kazakhstan: Silk Road synergy continues. New Delhi: Academic Excellence, lk 89-102.

Sańko 2012 = Sańko, Sergey. Podstawowe składniki białoruskiej narracji sakralnej w perspektywie porównawczej. Politeja. Journal of the Faculty of International and Political Studies of the Jagiellonian University 4. Kraków, lk 153-181. 
Sivitski 2006 = Sivitski, Uladzimir. Rusal'naia tradytsyia belarusay̆: mifapaetychnaia sistema, typalagichnyia paraleli. Minsk: Tekhnalogiia.

Šved 2006 = Shved, Ina. Kosmas $i$ chalavek $u$ dendralagichnym kodze belaruskaga fal'kloru. Brest: BrDU.

Šved 2008 = Shved, Ina. Dendralagichny kod belaruskaga tradytsyinaga fal'kloru: dys.... d-ra filal. navuk. Minsk.

Šved 2010 = Shved, Inna. Slovatskii fol'klor: formy, zhanry, poetika. Brest: Al'ternativa.

Šved 2011 = Shved, Ina. Mifalogiia koleru y̆ belaruskai tradytsyinai dukhoy̆nai kul'tury. Brest: BrDU.

Šved 2011a = Shved, Ina. Fal'klarystyka: dasledchyia pryiarytety i perspektyvy razvitstsia. Fal'klor i suchasnaia kul'tura. Materyialy III Mizhnarodnai navukovapraktychnai kanferentsyi: u 2 ch. Ch. 1. Minsk: BGU, lk 5-6.

TK 2011-2013 = Traditsionnaia khudozhestvennaia kul'tura belorusov. 1-10.

Toporkov 2002 = Toporkov, Andrei. $\mathrm{O}$ "Belorusskikh narodnykh predaniiakh" i ikh avtore. Toporkov, Andrei (koost). Rukopisi, kotorykh ne bylo: Poddelki v oblasti slavianskogo fol'klora. Moskva: Ladomir, lk 245-254.

Tšarota 2006, 2009, 2012 = Charota, Ivan. Narod serbski: iago abrady i zvychai, sviaty i sviatyni. Vyp. 1-3. Minsk.

Tšarota 2002 = Charota, Ivan (koost). Srpska krizheunost. Antologija tekstova. Kn. I. Minsk: BDU.

Valodzina 2009 = Valodzina, Tatsiana. Tsela chalaveka: slova, mif, rytual. Minsk: Tekhnalogiia.

Valodzina 2017 = Valodzina, Taćciana. Valgevene folkloori kogumik. Mäetagused 67, lk 261-262.

Valodzina \& Kuharonak 2015 = Valodzina, Tatsiana \& Kukharonak, Tatsiana. "Iadranoe zhyta gaspadara klicha...”: kaliandarny god u abradakh i zvychaiakh. Minsk: Belaruskaia navuka.

Volodina \& Mokienko 2018 = Volodina, Tat'iana \& Mokienko, Valerii. Russko-belorusskii slovar' sravnenii. Minsk: Belaruskaia navuka.

\section{Summary}

\section{Hotspots and successes in Belarusian folklore research in the 21st century}

\section{Tatsiana Valodzina}

Center for Belarussian Culture, Language and Literature Research

National Academy of Sciences, Belarus

tanja_volodina@tut.by

Keywords: anthropological folklore, Belarusian folklore, ethnolinguistics, fieldwork, genre system, mythology, worldview and codes 
The article gives an overview of the achievements in Belarusian folkloristics in the 21st century, highlighting the most vulnerable areas in folklore research, and trying to understand the reasons and prerequisites for successes and shortcomings in folkloristics.

The author is especially concerned about the shortage of professionals in the country to block the non-scientific publications. Although entertainment-specialised publications offer the reader exiting mythology, they also contain unsubstantiated generalisations made on the basis of traditions in a narrow region. This makes detailed research into folklore as a complete historical and cultural phenomenon the more essential. Therefore, Belarusian folklorists' most important direction of work is the recording of the folk heritage, identification of the typology of the folklore genres, determination of the spread areas of song melodies, dances, plots, motifs, and images, and preparation of collections revealing the richness of the cultural landscape of the Republic of Belarus in its regional and local peculiarities.

In 2013 the Centre of Fine Arts, Ethnography, and Folklore at the Belarusian Academy of Sciences launched an annual collection of scholarly articles under the heading Belarusian Folklore: Materials and Studies. The edition has already become a fruitful and interesting platform for discussing topical problems in folklore studies. The research covers the main directions of Belarusian folkloristics, and new approaches to study and understand the traditional world of Belarusian spiritual culture.

Tatsiana Valodzina (Tatjana Volodina) on valgevene folklorist, folkloristika ja slaavi rahvaste kultuuri sektori juhataja Valgevene Keele, Kultuuri ja Kirjanduse Instutuudis. Ta on ajakirja Belaruski fal'klor asutaja ja peatoimetaja, ajakiri ilmub alates 2014. aastast. Tema peamised uurimissuunad on rahvameditsiin, loitsud, kalendrikombestiku sümboolika ja semantika, sakraalsed maastikud, fraseoloogia ja folkloori lühivormid, lastefolkloor. Ta on kümne raamatu autor või kaasautor, avaldanud üle 200 teadusartikli. Ta on ka Valgevene-Eesti koostööväljaannete kaaskoostaja (2018, 2020).

Tatsiana Valodzina is Belarusian folklorist, head of the Department of Folkloristics and Culture of Slavic Peoples at the Institute of Belarusian Language, Culture, and Literature. She is the founder and editor-in-chief of the journal Belaruski fal'klor (Belarusian Folklore), which has been published since 2014. Her main research areas cover folk medicine, charms, symbols and semantics of calendar rituals, sacral landscapes, phraseology and short forms of folklore, and children's folklore. She has authored or co-authored ten books and published more than 200 scientific articles, and is also co-compiler of Belarusian-Estonian co-publications $(2018,2020)$.

tanja_volodina@tut.by 